\title{
Analisis Profil Fitokimia dan Aktivitas Antioksidan Ekstrak Etanol Daun, Kayu Dan Kulit Batang Tumbuhan Clausena lansium L.
}

\section{Phytochemical Profile Analysis and Antioxidant Activities from Ethanol Extract of Leaf, Stem Bark and Wood Clausena lansium L.}

\author{
Fajar Fauzi Abdullah ${ }^{1}$, Ruchiyat ${ }^{1}$, Iqbal Musthapa ${ }^{2 *}$ \\ ${ }^{1}$ Fakultas Matematika dan Ilmu Pengetahuan Alam Universitas Garut \\ Jl. Jati No. 42b Tarogong Kaler, Garut, Jawa Barat, Indonesia \\ ${ }^{2}$ Departemen Pendidikan Kimia, FPMIPA, Universitas Pendidikan Indonesia \\ Jl. Setiabudhi 229 Bandung, Jawa Barat, Indonesia \\ *E-mail: iqbalm@upi.edu
}

DOI: https://doi.org/10.26874/jkk.v3i1.48

Received: 10 March 2020, Revised: 31 May 2020, Accepted: 31 May 2020, Online: 31 May 2020

\begin{abstract}
Abstrak
Wampi (Clausena lansium L.) merupakan salah satu anggota famili Rutaceae. Tanaman ini berupa semak atau pohon kecil dengan buah mirip grapel atau seperti buah jeruk. $C$. lansium L. dilaporkan memiliki potensi aktivitas biologis, terutama sebagai penangkal radikal bebas. Tujuan penelitian ini adalah untuk mengidentifikasi kandungan golongan metabolit sekunder yang terdapat pada kulit kayu, kayu batang dan daun dari tumbuhan $C$. lansium L. serta untuk mengetahui aktivitas antioksidan melalui nilai $\mathrm{IC}_{50}$. Metode penelitian ini diawali dengan penyiapan sampel, determinasi tumbuhan, pemeriksaan karakteristik simplisia, pembuatan ekstrak dan uji aktivitas antioksidan, uji spektroskopi inframerah, pemeriksaan kromatografi lapis tipis (KLT), kemudian dilanjutkan dengan pengujian aktivitas antioksidan ekstrak etanol dengan menggunakan metode DPPH (2,2-Difenil-1-Pikrilhidrazil) dengan pembanding vitamin C. Hasil dari pengujian dengan spektroskopi inframerah dan KLT menunjukkan bahwa tumbuhan $C$. lansium L. mengandung senyawa golongan pemeriksaan alkaloid dan kumarin. Selanjutnya, pengujian aktivitas antioksidan menggunakan metode DPPH diukur serapan pada panjang gelombang $517 \mathrm{~nm}$ dengan pembanding vitamin C diperoleh nilai $\mathrm{IC}_{50}$ vitamin C 6,22 ppm; kulit kayu 231,54 ppm (lemah), kayu batang 131,49 ppm (lemah), dan daun 22,60 ppm (kuat).
\end{abstract}

Kata kunci: Clausena lansium, antioksidan, profil fitokimia.

\begin{abstract}
Wampi belongs to Rutaceae family. The shape of this plant is kind of bush or small tree and its fruits are similar to grapples or oranges. C. lansium was reported has the main biological activity as radical scavenger. The aim of this study to identify the content of secondary metabolites found in bark, woody stems and leaves of $C$. lansium plants, and to determine antioxidant activity through $I_{50}$ values. This research method begins with sample preparation, plant determination, simplicia characteristic examination, extraction, characterization with infrared spectroscopy, thin layer chromatography (TLC), then proceed with antioxidant activity assay using DPPH method (2.2 -Diphenyl-1picrylhidrazyl) with a comparison of vitamin $C$. The results of this study showed that $C$. lansium contains alkaloids and kumarin. Furthermore, antioxidant activity assay measured absorption at a wavelength of $517 \mathrm{~nm}$, obtained IC $C_{50}$ values of vitamin C 6.22 ppm; bark 231.54 ppm (weak), wood stem 131.49 ppm (weak), and leaves 22,60 ppm (strong).
\end{abstract}

Keywords: Clausena lansium, Antioxidant, phytochemical profile. 


\section{Pendahuluan}

radikal bebas merupakan salah satu penyebab berbagai penyakit dalam tubuh. Radikal bebas yaitu atom atau molekul yang memiliki satu atau lebih elektron tidak berpasangan. Radikal bebas dapat ditemukan di berbagai jenis bahan seperti logam (misalnya besi dan tembaga), asap rokok, obat-obatan, makanan dalam kemasan, dan bahan aditif [1].

Antioksidan merupakan suatu molekul pendonor elektron atau penghambat reaksi reduksi. antioksidan merupakan suatu senyawa yang mempunyai berat molekul yang kecil, dan dapat menginaktivasi proses terjadinya reaksi oksidasi, dengan menghambat terbentuknya radikal bebas dan molekul yang reaktif. Manfaat antioksidan yaitu menetralisir radikal bebas, sehingga mencegah dari penyakit degeneratif [2].

Berbagai jenis tanaman obat dan manfaatnya untuk kesehatan dan pengobatan berbagai penyakit telah dikenal sejak lama oleh masyarakat Indonesia. Tanaman obat yaitu jenis tanaman atau tumbuhan yang digunakan sebagai obat. Kegunaan tanaman obat tertentu diperoleh secara turun-temurun dan masih termanfaatkan hingga kini, dengan demikian pengobatan tradisional memegang peranan penting dalam kehidupan. Salah satu tanaman obat yang tumbuh di Indonesia yang berkhasiat sebagai obat yaitu tanaman wampee (Clausena lansium (Lour.) Skeels).

C. lansium L. merupakan tanaman yang termasuk ke dalam keluarga Rutaceae dan berasal dari Cina Selatan. Salah satu spesies tumbuhan genus Clausena yang digunakan sebagai obatobatan tradisional dan memiliki nama daerah wampee. Buahnya menyerupai lemon kecil dengan ukuran 2,0-4,0 cm, Rasanya agak sedikit asam, seperti jeruk bali saat dimasak. Bagian daun, akar dan buahnya telah digunakan dalam obat rakyat di Taiwan dan di Cina [3][4]. Tumbuhan Clausena ini dapat digunakan sebagai obat untuk antikanker, hepatoprotektif, antiplatelet, hipoglikemik, antijamur, antivirus, antioksidan [2]. Bagian dari akar C. lansium L. telah digunakan sebagai obat oleh rakyat Taiwan dan Cina untuk mengobati penyakit dermatologis tertentu sepeti hepatitis virus akut dan kronis, bagian buah di Filipina digunakan untuk influenza, pilek, nyeri abdomen, serta rebusan daun digunakan sebagai pencuci rambut untuk menghilangkan ketombe. Studi sebelumnya $C$. lansium L. mengandung alkaloid karbazol dan kumarin [2].

Berdasarkan latar belakang di atas masalah yang dapat diidentifikasi adalah komponen senyawa apa saja yang terkandung dalam ekstrak etanol daun, batang kayu dan kulit batang $C$. lansium L. serta apakah ekstrak etanol daun, batang kayu dan kulit $C$. lansium L. memiliki aktivitas antioksidan.

Tujuan dari penelitian ini yaitu untuk mengetahui adanya kandungan senyawa serta aktivitas antioksidan pada ekstrak etanol daun, batang kayu dan kulit batang wampee di Indonesia. Diharapkan dari penelitian ini dapat bermanfaat bagi perkembangan ilmu pengetahuan khususnya ilmu kefarmasian tentang antioksidan alami pada tanaman Indonesia spesies $C$. lansium L.

\section{Metode Penelitian}

\subsection{Alat}

Peralatan yang digunakan berupa desikator, cawan krus, kertas saring, tabung reaksi, Pipet tetes, mikropipet, corong pisah, batang pengaduk, kaca arloji, labu ukur, gelas kimia, gelas ukur, alat maserasi, alumunium foil, vial, rotary evaporator, kuvet, sortex, kompor listrik, pipa kapiler, lampu UV $254 \mathrm{~nm}$, lampu UV $365 \mathrm{~nm}$, spektrofotometri UV-VIS, dan timbangan analitik, spektroskopi Inframerah.

\subsection{Bahan}

Bahan yang digunakan pada penelitian kali ini adalah serbuk simplisia (Clausena launsium (Lour.) Skeel.) air suling, Etanol 96\%, Etil asetat, $n$-heksan, Diklorometan, $\mathrm{H}_{2} \mathrm{SO}_{4}, \mathrm{DPPH}(2,2-$ Difenil-1-Pikrilhidrazil), plat KLT alumunium berlapis silika gel $\mathrm{GF}_{254}$, alumunium foil, kertas whatman dan tissue lensa.

\subsection{Prosedur}

Determinasi dan penyiapan bahan bahan tanaman yang akan diteliti yaitu daun dan kulit batang tanaman $C$. lansium $\mathrm{L}$. atau biasa disebut dengan tanaman Wampee yang diambil dari Kebun Raya Bogor, Bogor Jawa Barat. Kemudian determinasi di Herbarium LIPI (Lembaga Ilmu Pengetahuan Indonesia) Pusat Penelitian Konservasi Tumbuhan dan Kebun Raya.

\subsection{Pembuatan Ekstrak Kental}

500 gram diekstraksi dengan metode dingin yaitu maserasi selama $3 \times 24$ jam menggunakan pelarut etanol 96\%. Ekstrak cair diuapkan dengan menggunakan alat rotary evaporator sampai diperoleh ekstrak kental. Kemudian ekstrak yang diperoleh dilakukan freeze dry untuk menghilangkan kadar air yang terkandung pada ekstrak [5].

\subsection{Karakterisasi Simplisia}

Pemeriksaan karakteristik simplisia meliputi 
pemeriksaan makroskopik, penetapan kadar abu total, penetapan kadar abu tidak larut asam, penetapan kadar abu larut air, penetapan kadar air, penetapan susut pengeringan, penetapan kadar sari larut air, dan penetapan kadar sari larut etanol.

\subsection{Analisa Spektroskopi Inframerah}

Dilakukan dengan cara menganalisis gugus fungsi senyawa yang terkandung di dalam sampel dengan menggunakan spektroskopi IR, Sampel ekstrak ditambahkan serbuk $\mathrm{KBr}$ digerus hingga homogen, dimasukkan ke alat pencetak pelet, dicetak menjadi pelet, dimasukkan ke dalam alat spektroskopi IR, dan dilakukan pengukuran spektrum.

\subsection{Analisa Kromatografi Lapis Tipis (KLT)}

Ekstrak ditotolkan pada plat KLT silika gel $\mathrm{GF}_{254}$ yang telah dielusi dengan fase gerak $n$ heksan:etil asetat (7:3), untuk menentukan bercak yang muncul. Bila fasa gerak telah mencapai batas yang ditentukan, plat diangkat dan dikeringkan diudara terbuka. Noda yang dihasilkan dideteksi di bawah sinar lampu ultraviolet dengan panjang gelombang $254 \mathrm{~nm}$ dan visibel dengan panjang gelombang $365 \mathrm{~nm}$. Kemudian spot noda yang muncul disemprot dengan penampak bercak universal $\mathrm{H}_{2} \mathrm{SO}_{4}$ dan penampak bercak Dragendroff untuk melihat senyawa golongan alkaloid.

\subsection{Pengujian Aktivitas Antioksidan}

Pengukuran aktivitas antioksidan kulit batang wampee menggunakan metode DPPH. Pembuatan larutan induk ekstrak daun dan kulit batang wampee sebanyak $100 \mathrm{~mL}$, dibuat dalam berbagai variasi konsentrasi 100 ppm, 200 ppm, 400 ppm, $600 \mathrm{ppm}$, dan 800 ppm. Untuk ekstrak daun dibuat seri larutan dengan konsentrasi 15 ppm, 20 ppm, $25 \mathrm{ppm}, 30 \mathrm{ppm}$ dan $35 \mathrm{ppm}$. Masing-masing konsentrasi diambil sebanyak $1 \mathrm{~mL}$ dimasukkan dalam tabung reaksi, kemudian ditambahkan $1 \mathrm{~mL}$ larutan DPPH. Kemudian divortex sekitar 3 detik hingga homogen, kemudian diinkubasi pada suhu $27^{\circ} \mathrm{C}$ selama 30 menit, diukur serapannya pada panjang gelombang $516 \mathrm{~nm}$ (panjang gelombang maksimum DPPH). Digunakan vitamin C sebagai pembanding. Dari pengujian akan menunjukkan nilai absorban dan dari hasil tersebut dapat dihitung untuk mendapatkan nilai $\mathrm{IC}_{50}$ dengan rumus:

$$
\text { Inhibisi }(\%)=\frac{\text { Absorbansi DPPH }- \text { Absorbansi sampel }}{\text { Absorbansi DPPH }} \times 100 \%
$$

\section{$3 \quad$ Hasil dan Diskusi}

\subsection{Karakterisasi Simplisia}

Proses pembuatan simplisia dari tanaman tersebut melalui beberapa proses. Mulai dari pengumpulan bahan, sortasi basah yang digunakan untuk memisahkan bahan dari pengotornya, pencucian yang bertujuan untuk menghilangkan pengotor yang masih menempel pada bahan dengan menggunakan air mengalir, selanjutnya adalah proses perajangan yang bertujuan memperkecil ukuran untuk mempercepat proses pengeringan. Kemudian dilakukan proses pengeringan yang bertujuan untuk memperoleh simplisia yang tidak mudah rusak dan dapat disimpan dalam waktu yang lama. Setelah itu dilakukan sortasi kering untuk memastikan tidak ada lagi pengotor pada simplisia, serta penggilingan simplisia yang bertujuan untuk memperkecil ukuran partikel simplisia sehingga pelarut dapat berpenertasi ke dalam membran sel simplisia semakin mudah dan memungkinkan senyawa yang terkandung dalam bahan lebih banyak tertarik. Selanjutnya proses penyimpanan dengan cara disimpan dalam wadah tertutup rapat pada suhu kamar yang bertujuan untuk memperpanjang masa simpan simplisia.

Pemeriksaan Simplisia diawali dengan pemeriksaan secara makroskopik kemudian dilanjutkan pemeriksaan karakterisasi simplisia yang terlihat pada tabel 1 dan 2. Pemeriksaan karakterisasi simplisia ini digunakan untuk mengetahui apakah sampel yang digunakan memenuhi standar simplisia.

Pada proses pembuatan ekstrak pada penelitian ini; serbuk dari daun , kayu batang, dan kulit batang masing-masing sebanyak 500 gram yang kemudian diekstraksi dengan cara maserasi dengan menggunakan pelarut etanol 96\%. Proses maserasi diulang sampai 3 kali 24 jam agar mendapatkan ekstrak yang maksimal. Kemudian dilakukan penyaringan dan kemudian penguapan dengan rotary evaporator sampai mendapat ekstrak pekat.

Tabel 1. Hasil pemeriksaan Makroskopis Simplisia C. lansium L.

\begin{tabular}{|c|l|c|c|c|}
\hline \multirow{2}{*}{ No } & \multirow{2}{*}{ Parameter } & \multicolumn{3}{|c|}{ Simplisia $C$. lansium L. } \\
\cline { 3 - 5 } & & Daun & Batang kayu & Kulit Batang \\
\hline $\mathbf{1}$ & Warna & Hijau tua & Putih gading & krem \\
\hline $\mathbf{2}$ & Bau & Khas & Khas & Khas \\
\hline $\mathbf{3}$ & Rasa & Agak pahit & Agak pahit & Agak pahit \\
\hline
\end{tabular}


Abdullah, F. F., et al./J. Kartika Kimia, Mei 2020, 3, (1), 13-18

Tabel 2. Hasil pemeriksaan Karakteristik Simplisia C. lansium L.

\begin{tabular}{|c|l|c|c|c|c|}
\hline \multirow{2}{*}{ No } & \multirow{2}{*}{ Pemeriksaan } & \multicolumn{3}{|c|}{ Kadar (\%) b/b } & \multirow{2}{*}{$\begin{array}{c}\text { Standar } \\
\text { FHI (\%) }\end{array}$} \\
\cline { 3 - 5 } & Daun & $\begin{array}{c}\text { Batang } \\
\text { kayu }\end{array}$ & $\begin{array}{c}\text { Kulit } \\
\text { Batang }\end{array}$ & $\leq 10$ \\
\hline 1 & Kadar air & 6.61 & $9,187^{*}$ & $5,3^{*}$ & $\leq 8,0$ \\
\hline 2 & Kadar abu total & 1.51 & 1,01 & 1,63 & - \\
\hline 3 & Kadar abu larut air & 0.88 & 0,822 & 0,66 & $\leq 1,2$ \\
\hline 4 & $\begin{array}{l}\text { Kadar abu tidak } \\
\text { larut asam }\end{array}$ & 0,06 & 0,033 & 0,07 & $\geq 17,0$ \\
\hline 5 & Kadar sari larut air & 21.65 & 3,22 & 14,9 & $\geq 4,2$ \\
\hline 6 & $\begin{array}{l}\text { Kadar sari larut } \\
\text { etanol }\end{array}$ & 24.34 & 2,25 & 9,4 & $\leq 9$ \\
\hline 7 & Susut Pengeringan & 8.01 & 7,681 & 6,3 & $\leq$ \\
\hline
\end{tabular}

\subsection{Analisa Spektroskopi Inframerah}
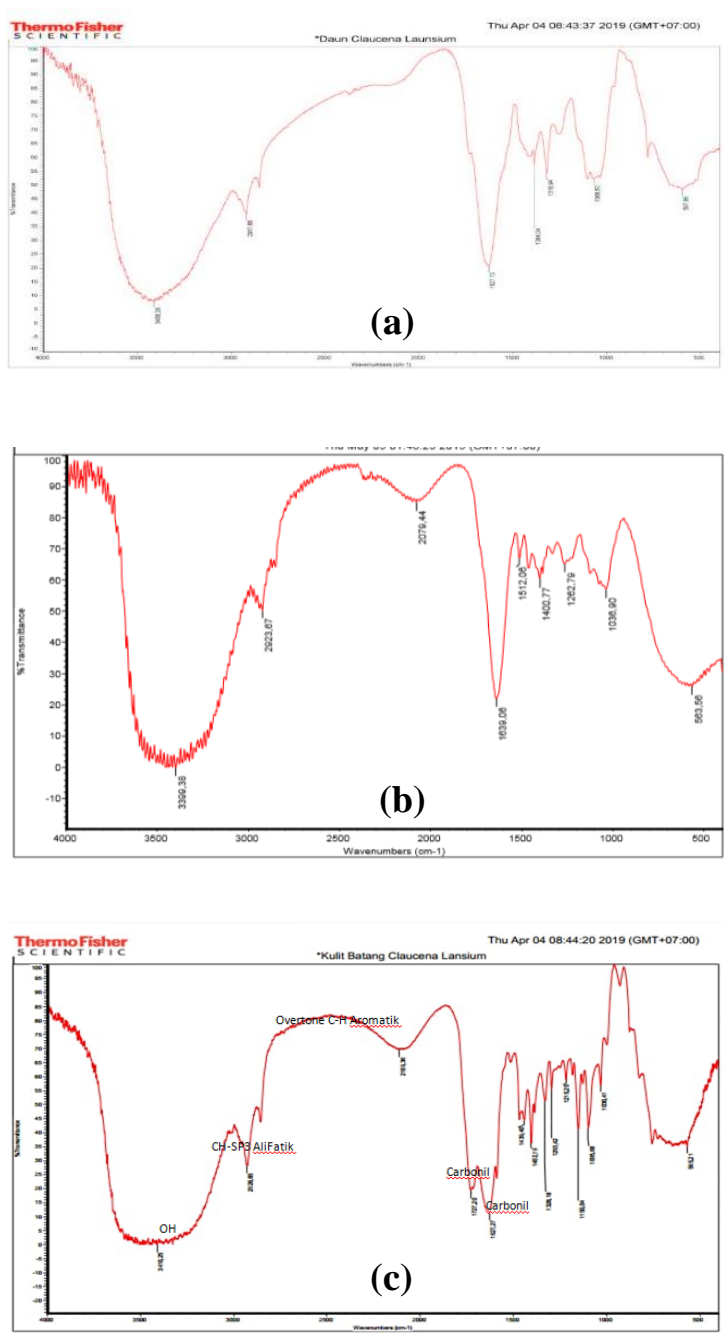

Tabel 5. Spektrum FT-IR Ekstrak etanol kulit batang $C$. lansium $L$.

\begin{tabular}{|c|c|c|c|c|}
\hline No & $\begin{array}{c}\text { Bilangan } \\
\text { Gelombang }\left(\mathbf{c m}^{-}\right. \\
\mathbf{1})\end{array}$ & $\begin{array}{c}\text { Bentuk } \\
\text { Pita }\end{array}$ & $\begin{array}{c}\text { Intensitas } \\
\text { Pita }\end{array}$ & $\begin{array}{c}\text { Prediksi } \\
\text { Gugus Fungsi }\end{array}$ \\
\hline 1 & 3410,25 & Lebar & Sedang & O-H \\
\hline 2 & 2928,85 & Tajam & Kuat & CH-sp $p^{3}$ \\
\hline 3 & 2109,36 & Lebar & Sedang & C-sp $p^{2}$ Aromatik \\
\hline 4 & 1727,20 & Tajam & Kuat & C=C Aromatik \\
\hline 5 & 1627,27 & Tajam & Kuat & C=C $s p^{2}$ \\
\hline
\end{tabular}

Tabel 3. Spektrum FT-IR Ekstrak etanol daun $C$. lansium $L$

\begin{tabular}{|c|c|c|c|c|}
\hline No & $\begin{array}{c}\text { Bilangan } \\
\text { Gelombang } \\
\left(\mathbf{c m}^{-\mathbf{1}}\right)\end{array}$ & $\begin{array}{c}\text { Bentuk } \\
\text { Pita }\end{array}$ & $\begin{array}{c}\text { Intensitas } \\
\text { Pita }\end{array}$ & $\begin{array}{c}\text { Prediksi Gugus } \\
\text { Fungsi }\end{array}$ \\
\hline 1 & 3408,26 & Lebar & Kuat & $-\mathrm{OH}$ \\
\hline 2 & 2917,66 & Tajam & Sedang & $\mathrm{C}-\mathrm{H} \mathrm{sp}{ }^{3}$ \\
\hline 3 & 1627,70 & Tajam & Kuat & $\mathrm{C}=\mathrm{O}$ \\
\hline 4 & 1384,04 & Tajam & Sedang & $\mathrm{C}=\mathrm{C}$ aromatik \\
\hline 5 & 1316,94 & Tajam & Sedang & C-N bending \\
\hline 6 & 1086,50 & Tajam & Sedang & C-O eter \\
\hline
\end{tabular}

Tabel 4. Spektrum FT-IR Ekstrak etanol batang kayu $C$. lansium $L$.

\begin{tabular}{|c|c|c|c|c|}
\hline No & $\begin{array}{c}\text { Bilangan } \\
\text { Gelombang }\left(\mathbf{c m}^{-}\right. \\
\mathbf{1})\end{array}$ & $\begin{array}{c}\text { Bentuk } \\
\text { Pita }\end{array}$ & $\begin{array}{c}\text { Intensitas } \\
\text { Pita }\end{array}$ & $\begin{array}{c}\text { Prediksi } \\
\text { Gugus Fungsi }\end{array}$ \\
\hline 1 & 3399,38 & Lebar & Kuat & - OH \\
\hline 2 & 2923,67 & Tajam & Sedang & C-H alifatik \\
\hline 3 & 1639,06 & Tajam & Kuat & Karbonil \\
\hline 4 & 1512,06 & Tajam & Sedang & C=C \\
\hline 5 & 1262,79 & Tajam & Kuar & C-N bending \\
\hline 6 & 1036,90 & Tajam & Sedang & C-O eter \\
\hline
\end{tabular}

Gambar 1. Gambar Spektrum FT-IR ekstrak etanol (a) daun; (b) batang kayu; (c) kulit batang C. lansium L. 


\subsection{Hasil Analisa KLT}

Hasil dari pemantauan KLT menggunakan eluen $n$-heksan:etil asetat (7:3) pada ekstrak etanol Daun C. lansium L. menghasilkan 3 spot yang terlihat di bawah UV $254 \mathrm{~nm}$ dan $365 \mathrm{~nm}$ yang menunjukkan noda berwarna biru kehijauan yang diduga sebagai senyawa kumarin dengan nilai Rf sebesar 0,36 dan noda berwarna merah yang merupakan noda dari klorofil dengan nilai $\mathrm{Rf}$ sebesar 0,51 dan 0,61 . Selanjutnya pada plat yang lain menggunakan sistem yang sama yang disemprot dengan penampak bercak Dragendroff menimbulkan warna noda jingga pada visual yang menunjukkan adanya senyawa alkaloid yang ditunjukkan dengan nilai $\mathrm{Rf}$ sebesar 0,29, dan menimbulkan warna noda biru kehijauan pada UV $365 \mathrm{~nm}$, terlihat pada Gambar 2.

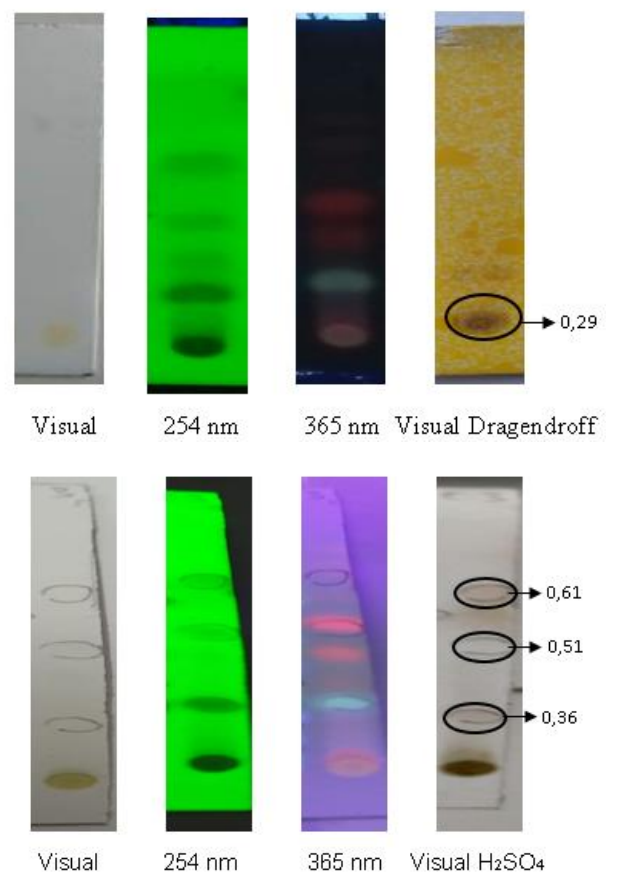

Gambar 2. Kromatogram KLT ekstrak etanol Daun C. lansium L.

Hasil dari pemantauan KLT ekstrak etanol Kayu batang C. lansium L. Gambar 3. Plat yang sudah disemprot diamati di bawah sinar UV 365 $\mathrm{nm}$ dan memperlihatkan 6 noda dengan $\mathrm{Rf}$ yang berbeda-beda yaitu $\operatorname{Rf} 1=0,1 ; \operatorname{Rf} 2=0,34$; Rf 3= 0,$6 ; \operatorname{Rf} 4=0,7 ; \operatorname{Rf} 5=0,98$ dan $\operatorname{Rf} 6=1$. Sedangkan pereaksi warna lainnya seperti Dragendroff digunakan untuk mendeteksi senyawa alkaloid. Pereaksi Dragendroff menunjukkan hasil yang positif ditandai dengan perubahan warna menjadi jingga coklat atau orange.

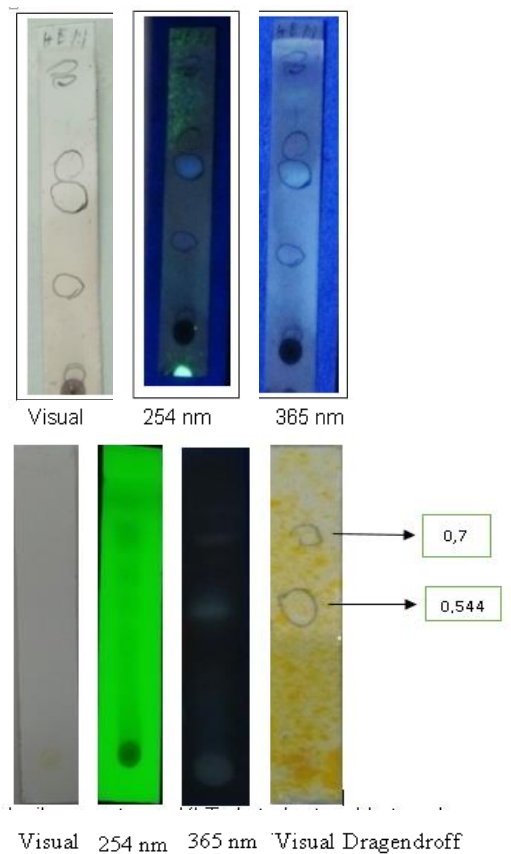

Gambar 3. Kromatogram KLT ekstrak etanol Batang Kayu C. lansium L.

Hasil dari pemantauan KLT ekstrak etanol kulit batang $C$. lansium L. Gambar 4. menghasilkan 8 spot yang terlihat di bawah UV $254 \mathrm{~nm}$ dengan $\mathrm{Rf} 10,7$; Rf 2 0,6; Rf3 0,4; Rf4 0,36; Rf5 0,3; Rf6 0,26; Rf7 0,2; Rf8 0,12. Sedangkan pada sinar UV $365 \mathrm{~nm}$ menghasilkan 7 spot menunjukkan noda berwarna biru dengan $\mathrm{Rf}$ berturut-turut Rf10,6; Rf2 0,4; Rf3 0,3; Rf4 0,3; Rf5 0,26; Rf6 0,2; Rf7 0,12.

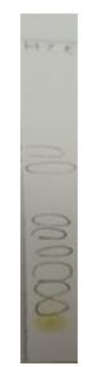

Visual

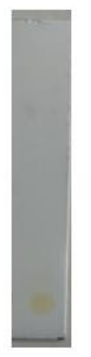

Visual

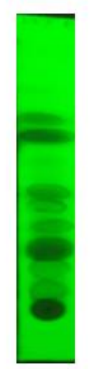

$254 \mathrm{~nm}$

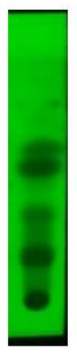

$254 \mathrm{~nm}$

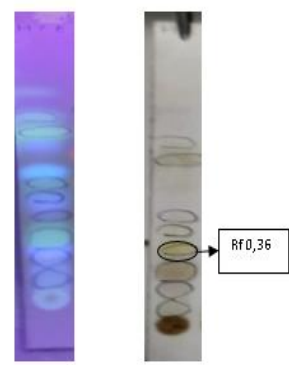

$365 \mathrm{~nm}$ Visual $\mathrm{H}_{2} \mathrm{SO}_{4}$

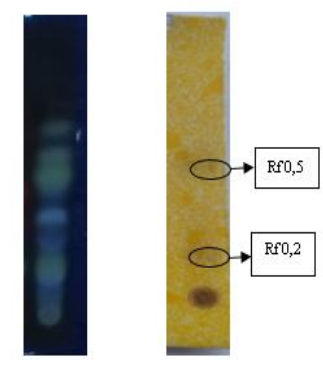

365 nm Visual Dragendroff
Gambar 4. Kromatogram KLT ekstrak etanol Kulit Batang C. lansium L. 


\subsection{Hasil Pengujian Aktivitas Antioksidan}

Tabel 6. Hasil nilai $\mathrm{IC}_{50}$ Standar dan Masingmasing Ekstrak etanol terhadap pengujian Antioksidan DPPH

\begin{tabular}{|c|c|c|}
\hline No & Sampel & $\begin{array}{c}\text { IC50 } \\
(\mathbf{p p m})\end{array}$ \\
\hline 1 & Vitamin C ( Standar) & 6,22 \\
\hline 2 & $\begin{array}{c}\text { Ekstrak Etanol Daun C. lansium L.. } \\
\text { Ekstrak Etanol Kayu Batang C. } \\
\text { lansium L. }\end{array}$ & 22,60 \\
\hline 4 & $\begin{array}{c}\text { Ekstrak Etanol Kulit Kayu } \text { C. } \\
\text { lansium L. }\end{array}$ & 231,49 \\
\hline
\end{tabular}

\section{Kesimpulan}

Berdasarkan hasil penelitian yang telah dilakukan dari analisis profil fitokimia dari ekstrak etanol Daun, Kayu Batang, dan Kulit batang $C$. lansium L. mengandung senyawa metabolit sekunder, diantaranya monoterpen, alkaloid dan cumarin selanjutnya hasil dari spektroskopi Inframerah, dapat ditunjukkan adanya gugus $\mathrm{O}-\mathrm{H}$, $\mathrm{C}-\mathrm{H} \mathrm{sp}{ }^{3}, \mathrm{C}-\mathrm{sp}^{2}$ Aromatik, C=C (Aromatik), dan $\mathrm{C}=\mathrm{C} \quad \mathrm{sp} 2$. Kemudian diperkuat dengan pemantauan KLT dengan menggunakan penampak bercak universal $\mathrm{H}_{2} \mathrm{SO}_{4}$ dan bercak spesifik Dragendorf. Selanjutnya, pengujian aktivitas antioksidan menggunakan metode DPPH diukur serapan pada panjang gelombang $517 \mathrm{~nm}$ dengan pembanding vitamin $\mathrm{C}$ diperoleh nilai $\mathrm{IC}_{50}$ vitamin C 6,22 ppm; kulit kayu 231,54 ppm (lemah), kayu batang 131,49 ppm (lemah), dan daun 22,60 ppm (kuat).

\section{Ucapan Terima Kasih}

Terima kasih kami sampaikan pada pihak Kebun Raya LIPI BOGOR, atas bantuan penyediaan dan determinasi sampel.

\section{Daftar Pustaka}

[1] Ismail AA, Ahmad BA, Mohamed A, RasedeeAbdullah, Siddig IA, Mohamed YI, et al. A review of traditional uses, phytochemical and pharmacological aspects of selected members of Clausena genus (Rutaceae). J Med Plants Res. 2012. 6(38):5107-18.

http://dx.doi.org/10.5897/jmpr12.317

[2] Prasad KN, Hao J, Yi C, Zhang D, Qiu S, Jiang $\mathrm{Y}$, et al. Antioxidant and anticancer activities of wampee (Clausena lansium (Lour.) Skeels) peel. J Biomed Biotechnol. 2009/07/30. 2009. 2009:612805. https://pubmed.ncbi.nlm.nih.gov/19657451

[3] Maneerat W, Prawat U, Saewan N, Laphookhieo S. New coumarins from Clausena lansium twigs. J Braz Chem Soc. 2010.21(4):665-8.

http://dx.doi.org/10.1590/s010350532010000400012

[4] Liu J, Li C-J, Du Y-Q, Li L, Sun H, Chen N$\mathrm{H}$, et al. Bioactive Compounds from the Stems of Clausena lansium. Molecules. 2017. 22(12):2226. https://pubmed.ncbi.nlm.nih.gov/29240703

[5] Adebajo AC, Iwalewa EO, Obuotor EM, Ibikunle GF, Omisore NO, Adewunmi CO, et al. Pharmacological properties of the extract and some isolated compounds of Clausena lansium stem bark: Anti-trichomonal, antidiabetic, anti-inflammatory, hepatoprotective and antioxidant effects. $J$ Ethnopharmacol. 2009. 122(1):10-9. http://dx.doi.org/10.1016/j.jep.2008.11.015 